УДК $(94: 27)(477.61)$ «19/20...»

DOI: https://doi.org/10.33782/2708-4116.2020.2.29

Микола Рубан

\title{
ІСТОРІЯ ТА ПЕРСПЕКТИВИ ВІДНОВЛЕННЯ МИКІЛЬСЬКОЇ ПАРАФІЇ СЕЛА ВОВКОДАЄВЕ НОВОАЙДАРСЬКОГО РАЙОНУ ЛУГАНСЬКОЇ ОБЛАСТІ
}

Анотація: У статті здійснено спробу дослідити історію заснування та перспективи розвитку Микільської парафії селища Вовкодаєве Новоайдарського району Луганської області. Наведено біографічні відомості щодо останнього багатолітнього настоятеля вовкодаївської громади репресованого священика Митрофана Таранського. Розглянуто обставини інституалізації Православної Церкви на Старобільщині, зокрема місцевої єпархї̈ обновленської Української Синодальної Церкви, а також події довкола закриття храму села Вовкодаєво на тлі загальної реалізації антирелігійної політики радянського партійного керівництва та ліквідації структур відособлених реформаційних православних конфесій на Луганщині 1930-хрр. З'ясовано обставини повернення експропрійованої будівлі Микільського храму відновленій громаді у складі ЛуганськоСтаробільської єпархії УПЦ Київького Патріархату на початку 2000-х рр. Визначено можливі шляхи реконструкиії храмової споруди та запропоновано стратегію фактичного відновлення діяльності парафіі.

Доведено, що за обмежених наявних ресурсів відновлення діяльності громади та ревіталізація храмової будівлі можливі лише за умови створення на ї місиі монастиря - паломницького центру, що, у свою чергу, також дозволить здійснювати ефективну місіонерську діяльність серед місцевих представників дисидентських православних громад.

Проаналізовано історію розвитку православного чернецтва та досвід формування мережі монастирів на місці історичних церков на території Луганської області.

Ключові слова: православ'я, Вовкодаєво, Микільський храм, монастир, чернещтво, місіонерська діяльність

Побудова комуністичного суспільства в Україні протягом 1920-1930-х рр. супроводжувалася впровадженням репресивних заходів по відношенню до релігійних організацій. Засилля каральних заходів призвело до майже цілковитого припинення легального парафіяльного життя на території регіону в середині 1930-х рр. Утім, попри знищення організованої церковної структури, віра в народі не згасла і навіть місцеві чекісти визнавали існування широкої підтримки катакомбних священнослужителів навіть серед насе-

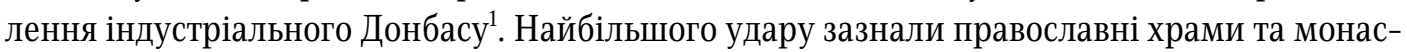
тирі, більшість з яких мала важливе історичне значення. Не стала винятком і старовинна

\footnotetext{
" Рубан Микола Юрійович - аспірант Східноукраїнського національного університету імені Володимира Даля (м. Сєвєродонецьк), магістр Київської православної богословської академії (м. Київ), диякон Православної Церкви України; ORCID: https://orcid.org/0000-0002-6396-4531; e-mail: nikolas.kindle@gmail.com

${ }^{1}$ Куромія Г. Свобода і терор у Донбасі: Українсько-російське прикордоння, 1880-1990-ті роки. [пер. 3 англ. Г. Кьоран; В. Агеєв; передм. Г. Немирі]. Київ: Видавництво Соломії Павличко «Основи», 2002. С. 340.
} 
Микільська церква села Вовкодаєве - духовна пам'ятка Луганщини початку XIX ст. Питання щодо відновлення храму постало на початку 2000-х рр. на хвилі лібералізації державної релігійної політики та повернення експропрійованого майна Православній ЦеркBi.

Отже, предметом даної наукової розвідки виступає історія Микільської парафії села Вовкодаєве Новоайдарського району Луганської області. Актуальність вивчення цієї теми полягає в потребі належного осмислення й усвідомлення історичних обставин виникнення та наслідків релігійно-світоглядної кризи частини населення промислового регіону, викликаної антропологічними експериментами більшовицьких ідеологів з формування нового типу людини комуністичного толку, а надто ж, виходячи з викликів сьогодення пошуку можливих шляхів відновлення Микільської громади УПЦ Київського Патріархату (нині - ПЦУ) в селі Вовкодаєве.

Аналіз досліджень і публікацій. Дослідженню історії храмів Луганщини присвячені роботи О. Форостюка ${ }^{2}$, який фактично започаткував вивчення церковного краєзнавства регіону, О. Смоліної ${ }^{3}$ та харківського дослідника А. Парамонова ${ }^{4}$. 3'ясуванню окремих маловідомих аспектів розвитку інституцій православних конфесій на Донбасі протягом $\mathrm{XX}$ ст. присвячено низку робіт автора ${ }^{5}$. Утім, вказана історіографія не вичерпує повноти окресленого завдання, оскільки існує чимало питань, що потребують свого уточнення та належного розкриття.

Мета статті полягає у висвітленні історичних обставин функціонування давнього Микільського храму села Вовкодаєве Новоайдарського району Луганської області на основі нових історичних джерел і наукової літератури.

Утвердження Православ'я на сході України розпочалося із слов'янською колонізацією територій уздовж річок Сіверський Донець, Айдар, Деркул, Євсуг тощо наприкінці XVI - XVII ст. Більшість переселенців - українці, росіяни, серби - сповідувала православну віру. Село Вовкодаєве було засноване поблизу р. Журавки (притока Євсуга) в 1749 р. Назва селища походить від прізвища його першого поселенця - Вовкодав ${ }^{6}$. Існують також відомості, що деякий час село мало назву Журавка ${ }^{7}$ Кам'яний однопрестольний храм на честь святителя Миколи Чудотворця при слободі Вовкодавової був побудований коштом громади у 1818 р. Упродовж 1830-1850 рр. загальна кількість парафіян зросла з 1168 до

\footnotetext{
${ }^{2}$ Форостюк О.Д. Православная Луганщина в годы гонений и трагических испытаний (1917-1988 гг.). Луганск, 1999. 120 с.; Форостюк О.Д. Луганщина релігійна. Історичний і правовий аспекти. Луганськ, 2004. 206 с.; Форостюк О.Д. Правове регулювання державно-церковних відносин у радянській Україні в 1917-1941 роках (на матеріалі Донецького регіону): Монографія. Луганськ: РВВ ЛІВС, 2000. 151 с.

${ }^{3}$ Смолина О.О. Монастыри Слобожанщины: динамика художественного образа. Монография. Северодонецк: Изд-во ВНУ им. В. Даля, 2016. 300 с.

${ }^{4}$ Парамонов А.Ф. Материалы по истории православных храмов Луганской области Харьков: Харьковский частный музей городской усадьбы, 2013. 154 с.

${ }^{5}$ Ruban M.Y. The organizational development of the renovationist movement in the Starobilsk region in 1922-1930. Вісник Східноукраїнського національного університету імені Володимира Даля. 2019. № 4 (252). С. 66-69.

${ }^{6}$ Міста і села України. Луганщина: історико-краєзнавчі нариси / упор. В.В. Болгов. Київ: Українська академія геральдики, товарного знаку та логотипу, 2012. С. 286.

${ }^{7}$ Врятована пам'ять. Голодомор 1932-33 років на Луганщині: свідчення очевидців. Т. 1. Упорядн. I. Магрицька. Луганськ: Промдрук. 2008. С. 142.
} 
1423 осіб. Під час епідемій холери у 1831 р. померло 8 парафіян, а в 1848 р. - $10^{8}$. До 1840 року в селі нараховувалось близько 230 дворів, працювала крамниця, 30 вітряних млинів, олійниця та кузня. Жителі займалися землеробством і тваринництвом. Станом на 1904 p. при Микільській церкві було 49,5 десятин пахотної та сінокосної землі. Церковне піклування було відсутнє. Парафіян чоловічої статі нараховувалося 1064, жіночої - 1077 осіб. Причтовий капітал складав 500 руб. За штатом при храмі числились священик і псаломщик. Платня священика складала 141 руб. 12 коп., псаломщика - 35 руб. 28 коп. Священик проживав у громадському будинку, а псаломщик - власному. При церкві діяла парафіяльна школа. Настоятель - священик Митрофан Таранський, студент семінарії, у священному сані з 1891 р. при цій церкві. Завідувач і законовчитель церковнопарафіяльної школи. Викладав Закон Божий у народному училищі 5 округу. Нагороджений скуфією в 1896 р. Псаломщик Порфирій Чебанов - 60 років, випускник духовного училища, пономар з 1859 р., при вказаній церкві з 1879 р. Церковний староста селянин Петро Скубко з 1882 p. $^{9}$

Священик Митрофан Федорович Таранський народився 4 червня 1864 р. на Ізюмщині. 31891 р. і до закриття парафії служив священиком у селі Вовкодаєве. Родина складалася $з$ дружини Марії 1862 р. народження і двох синів. У власності клірика були три великі будинки у Старобільську, які він здавав, а в самому селі Вовкодаєве - 56 десятин землі, будинок на десять кімнат, два піаніно, що на той час вважалося величезною розкішшю, десять комор, четверо коней, четверо корів, близько сотні овець і сто вуликів. При господарстві було двоє постійних працівників і 20-30 сезонних ${ }^{10}$. у 1910 р. коштом настоятеля будівля Микільської церкви села Вовкодаєве була реконструйована, а через чотири роки іï знову перебудували, додавши два куполи та дзвіницю з п'ятьма дзвонами. Основний дзвін важив близько 600 кілограм ${ }^{11}$.

На початку XX ст. парафії Старобільського повіту належали до складу Харківської єпархії, 14 травня 1916 р. у складі єпархії був утворений Старобільський вікаріат. Революційні події 1917-1921рр. та пов'язані з ними зміни державно-церковних відносин сприяли організаційному становленню руху за оновлення внутрішньоцерковного життя та подальшої інституалізації відособлених реформаційних конфесій на території СРСР. В Україні обновленська ідеологія зазнала суттєвий вплив самостійницьких настроїв, а ії фактичне втілення було здійснене вже в межах «Канонів Української Православної Церкви» УАПЦ, які, за слушним твердженням А. Зінченка, мали «значення новітньої української церков-

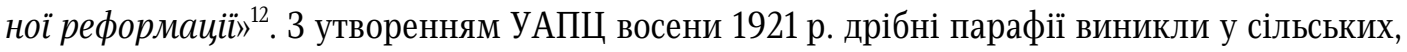
переважно україномовних, районах Донецької губернії. Адміністративно ці парафії на-

\footnotetext{
${ }^{8}$ Филарет (Д.Г. Гумилевский), свт. Историко-статистическое описание Харьковской епархии: в 2-х томах. Харьков: Харьковский частный музей городской усадьбы, 2011. Т. 2. С. 312.

${ }^{9}$ Самойлович И. Справочная книга для Харьковской епархии. Харьков, 1904. С. 426.

${ }^{10}$ Таранский Митрофан Федорович. Бессмертный барак. URL: https://bessmertnybarak.ru/taranskiy_mitrofan_fedorovich/

${ }^{11}$ Міста і села України. Луганщина: історико-краєзнавчі нариси. С. 286.

${ }^{12}$ Зінченко А.Л. Всеукраїнський Православний Церковний Собор. Енциклопеділ історії України: T. 1: А-В. Редкол.: В.А. Смолій (голова) та ін. НАН України. Інститут історії України. Київ: «Наукова думка», 2003. С. 660661.
} 
лежали до Харківсько-Слобожанської Округової Ради ${ }^{13}$. Зрештою, поява нової конфесії не викликала суттєвих змін в організаційній структурі Православної Церкви на Старобільщині, оскільки, за офіційними даними, на території округи діяло лише 2 парафії УАПЦ. Перші обновленські громади майбутньої Синодальної Церкви на Старобільщині з'явились у січні 1923 p. ${ }^{14} 5$ грудня 1922 р. у Москві відбулась архієрейська хіротонія обновленського вікарія Харківської єпархії - єпископа Старобільського Олександра (Мігуліна $)^{15}$, і, вже незабаром, ієрарх був обраний головою місцевого вікарного управління. За цікавим спостереженням О. Форостюка, новохіротонісаний архієрей розгорнув широку діяльність щодо переведення храмів, однак, не зустрів підтримки релігійних мас ${ }^{16}$. Станом на 1 жовтня 1923 р. на території Старобільського повіту до юрисдикції обновленської Церкви належало лише 27 із 150 офіційно зареєстрованих парафій ${ }^{17}$.

8-9 травня 1924 р. у Покровському соборі м. Старобільськ відбувся окружний з'їзд духовенства та мирян за участі одного з провідних ідеологів церковної реформації в Україні - єпископа Ізюмського Йосифа (Кречетовича). У перший день в роботі з'їзду взяли участь 292 делегати, утім, вже на другий день було зареєстровано лише 168 осіб ${ }^{18}$. На з'їзді було також порушене питання щодо обрання нового окружного архієрея, однак, вибори так і не відбулись, натомість незабаром Всеукраїнський Синод призначив головою Старобільського окружного церковного управління новохіротонісаного єпископа Мелетія (Фоміна) ${ }^{19}$.

Відповідно до нової адміністративної реформи УСРР у червні 1925 р. Священний Синод Української Синодальної Церкви здійснив реорганізацію мережі єпархіальних управлінь. У результаті цього було утворено 36 єпархій у межах територіальних округ, у тому числі зі складу Харківської єпархії виокремлено Старобільську єпархію ${ }^{20}$.

У 1926 р. Микільська громада с. Вовкодаєве увійшла до складу Старобільської єпархії Синодальної Церкви ${ }^{21}$. Навесні 1928 р. на території Старобільської округи перебувало 62 парафії Синодальної Церкви 22 , була однією з найбільших на території колишньої Донецької губернії. у листопаді 1928 р. єпископ Старобільський Мелетій (Фомін) очолив Кам'янець-Подільське єпархіальне управління, натомість Старобільська кафедра до часу свого фактичного скасування лишалась вакантною.

\footnotetext{
${ }^{13}$ Майстренко В.С., Корнєв О.В. Українська Автокефальна Православна Церква в історії Слобожанщини та Донбасу (1926-1930 рр.). Вісник Харківського національного університету імені В.Н. Каразіна. Сер.: Історія. 2008. № 816. С. 146-147.

${ }^{14}$ Форостюк О.Д. Правове регулювання державно-церковних відносин у радянській Україні в 1917-1941 роках (на матеріалі Донецького регіону). С. 73.

${ }^{15}$ Лавринов В., прот. Обновленческий раскол в портретах его деятелей. Москва: Общество любителей церковной истории, 2017. С. 59.

${ }^{16}$ Форостюк О.Д. Правове регулювання державно-церковних відносин у радянській Україні в 1917-1941 роках (на матеріалі Донецького регіону). С. 73.

${ }^{17}$ Там само. С. 73-74.

${ }^{18}$ Съезд духовенства и мирян Старобельского округа. Червоний хлібороб (Старобільськ). 1924. 18 травня (№ 17). C. 2 .

${ }^{19}$ Лавринов В., прот. Обновленческий раскол в портретах его деятелей... С. 354.

${ }^{20}$ Ruban M.Y. The organizational development of the renovationist movement in the Starobilsk region in 19221930. C. 67.

${ }^{21}$ Державний архів Луганської області. Ф. Р-1281. Оп. 1. Спр. 3. Арк. 334.

${ }^{22}$ У нас: На Старобельщине. Украӥнський православний благовісник. 1928. № 5 (1 березня). С. 13.
} 
У 1929 р. у Вовкодаєвому був проведений мітинг з нагоди 12-ї річниці Жовтневої революції, на якому пролунали вимоги закрити у селі церкву. Підхопивши цю ідею, місцеві активісти відібрали у вірян ключі від церкви, порозбивали ікони і на знак перемоги встановили на дзвіниці червоний прапор. Утім, позаяк центральна влада на той час ще підтримувала Синодальну Церкву, до складу якої належала місцева парафія, дозвіл на закриття громади не був наданий ${ }^{23}$.

у 1932-1933 рр. с. Вовкодаєве постраждало від Голодомору²4, під час якого в 1932 р. зрештою була скасована Микільська громада. Дізнавшись про це, люди встали на захист своєї святині - зібралися навколо церкви і, взявшись за руки, протягом деякого часу не допускали до храму безвірників ${ }^{25}$. Згодом храмова будівля використовувалась як зерновий склад ${ }^{26}$. Водночас розпочалась активна ліквідація решти діючих парафій Синодальної Церкви. У період з травня 1927 р. по серпень 1935 р. на території округи було закрито 53 храми, i станом на червень 1935 р. на Старобільщині функціонувало лише 3 обновленські громади ${ }^{27}$.

У 1937 р. купол і дзвіниця Микільського храму були розібрані, а з отриманого матеріалу - побудовано школу в с. Євсуг ${ }^{28}$. Однак, попри засилля репресивних заходів, ще досить тривалий час богоборча влада не була спроможна зломити тверду підтримку Христової віри в народі. У березні 1937 р. голова Донецького управління НКВС Іванов наголошував, що «дуже багато бродячих ченців, попів без парафій та іншої шпани мешкає у ре-

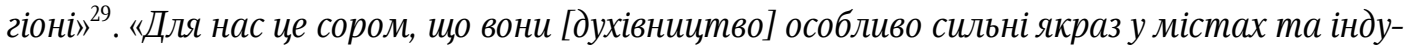
стріальних регіонах» - зазначав чекіст ${ }^{30}$. 3 огляду на це місцеві активісти усіляко прагнули знищити саму згадку про історичну тяглість Православ'я відображену в численних історичних пам'ятках Луганщини, й усього Донбасу зокрема.

На хвилі закриття храмів колишній багатолітній настоятель вовкодаєвської громади священик Митрофан Таранський переїхав до Ворошиловграду, де і був заарештований 27 жовтня 1937 р. Під час обшуку в нього було вилучено срібний і мідний хрести, паспорт і 10 листів. Селяни звинувачували клірика у видачі білогвардійцям голови сільради I. Шана, співпраці з антибільшовицькими загонами місцевого отамана Івана Каменюки, організації кулацького повстання в селі у 1920 р. та спротиву колективізації, наслідком якої було розвалення місцевого колгоспу. Попри категоричні заперечення кліриком названих фактів, 4 листопада 1937 р. Особливою нарадою при НКВС СРСР священик Митрофан Таранський був засуджений до розстрілу ${ }^{31}$. За результатами «Безбожної п'ятирічки»

\footnotetext{
${ }_{23}^{23}$ Форостюк О.Д. Луганщина релігійна. Історичний і правовий аспекти. С. 145-146.

${ }^{24}$ Врятована пам'ять. Голодомор 1932-33 років на Луганщині: свідчення очевидців. Т. 1. С. 219-220.

${ }^{25}$ Форостюк О.Д. Луганщина релігійна. Історичний і правовий аспекти. С. 145-146.

${ }^{26}$ Сумішин Ю.С, Корнєєв Є.С, Брель Я.М., Кравченко Г.М. Луганська єпархія. Інформаційно-довідкове видання [під загальною редакцією секретаря Лугансько-Алчевської єпархії прот. Іакова Лобова]. Луганськ, 2011. C. 302.

${ }^{27}$ Форостюк О.Д. Правове регулювання державно-церковних відносин у радянській Україні в 1917 - 1941 роках (на матеріалі Донецького регіону). С. 130.

${ }^{28}$ Сумішин Ю.С., Корнєєв Є.С., Брель Я.М., Кравченко Г.М. Луганська єпархія. Інформаційно-довідкове видання. С. 302.

${ }^{29}$ Куромія Г. Свобода і терор у Донбасі: Українсько-російське прикордоння, 1880-1990-ті роки. С. 340.

30 Там само.

${ }^{31}$ Реабілітовані історією: Луганська область. Книга 3. Луганськ, 2008. С. 399. Таранский Митрофан Федорович. Бессмертный барак. URL: https://bessmertnybarak.ru/taranskiy_mitrofan_fedorovich/
} 
(1932-1937 рр.) на Луганщині до початку Німецько-радянської війни залишалась тільки одна діюча парафія ${ }^{32}$.

4 травня 2001 р. занедбана будівля Микільського храму села Вовкодаєве була передана місцевій громаді УПЦ Київського Патріархату, настоятелем якої - донецьким священиком Андрієм Чуєм - здійснювались заходи щодо організації ремонтних робіт ${ }^{33}$. Перша Микільська парафія УПЦ Київського Патріархату з'явилася у Луганську наприкінці 1995 р. 15 грудня 1999 р. Ухвалою Священного Синоду УПЦ Київського Патріархату Донецько-Луганська єпархія була розділена на Донецьку та Луганську, тимчасове керівництво якою було доручено єпископу Донецькому та Маріупольському Юрію (Юрчику) ${ }^{34}$. За даними перепису 2001 р. населення с. Вовкодаєве становило 579 осіб, з них 88,43\% зазначили рідною українську мову, а 11,57\% - російську ${ }^{35}$. Отже, 3 огляду на малочисельність наявних ресурсів і відсутність перспектив щодо відновлення громади силами місцевого населення, вважаємо за доцільне розглянути можливість альтернативних варіантів ревіталізації храмової будівлі в рамках церковних канонів.

На Луганщині існує позитивний досвід відновлення храмових споруд шляхом утворення при них монастирів. Чернецтво в Луганському краї бере свій початок з часів поширення християнства у Дикому полі. Першим подвижником, про якого є письмова згадка, був відомий серед запорізьких козаків у XVIII ст. пустельник Петро Довгаль, відставний військовий старшина, який, усамітнившись поблизу сучасного с. Красний Кут, присвятив решту свого життя служінню Богу. Запорожці постійно приходили до нього на поклін і для духовних бесід ${ }^{36}$. На півночі області у XVIII-XIX ст. жив старець Дмитро Горський. У XIX ст. чотири монахи намагалися заснувати під Новопсковим печерний скит, але незабаром були вигнані поліцією. У 1886 р. у Старобільську був заснований Скорботницький монастир, у 1905 р. поблизу Сватового був заснований Успенсько-Серафимівський монастир, а в 1912 р. Троїцький монастир був відкритий у Луганську. У міжвоєнний період чернецтво на Донбасі зіграло важливу роль у ствердженні Істинно-православної Церкви. Консервативну церковну опозицію підтримували монахині Старобільської та УспенськоСерафимівської обителів, а також окремі ченці Троїцького монастиря (м. Луганськ). у 1951 р. у передмісті Луганська був заснований підпільний монастир, постриги в якому здійснював колишній насельник Троїцького монастиря ієромонах Никострат (Кожушко). У 1950 рр. бурхливу дисидентську діяльність у регіоні розгорнули лідери групи ІПХ Краснодонського району Г. Цимбал і П. Сорокін, які писали й роздавали апокаліптичноесхатологічну літературу власного авторства ${ }^{37}$.

Особливим місцем паломництва на Луганщині є Киселева балка. За народними переказами, перше зцілення у Киселевій балці сталося над сліпонародженим хлопчиком у

\footnotetext{
32 Форостюк О.Д. Луганщина релігійна. Історичний і правовий аспекти. С. 29.

${ }^{33}$ Там само. С. 32, 145-146.

${ }^{34}$ Журнали засідань Священного Синоду Української Православної Церкви Київського Патріархату від 15 грудня 1999 року. Православний вісник. 1999. №11-12. С. 8-9.

${ }^{35}$ Кількість наявного населення по кожному сільському населеному пункту, Луганська область (осіб) с. Вовкодаєве, 05.12.2001. URL: http://database.ukrcensus.gov.ua/MULT/Dialog/Saveshow.asp

${ }^{36}$ Весь Луганск в кармане: Адрес-календарь и справочная книга города и окрестностей на 1912 год, I год изданія. Луганск: Изданіе Е. Шнирлина и М. Кулашкина, 1912. С. 111.

${ }^{37}$ Форостюк О.Д. Луганщина релігійна. Історичний і правовий аспекти. С. 37-38.
} 
1720 р. На початку 1920-х років, як йдеться в іншому народному переказі, коло дерева «П’яти братів» біля джерела з'явилася Божа Матір, після чого на цьому місці немічні стали отримувати зцілення. Щоденно джерело відвідувало близько двох тисяч осіб. У лютому 2000 р. у Киселевій балці оселились кілька послушників, які мали покласти початок Благовіщенському скиту. Утім, проти заснування скиту виступали деякі чиновники, оскільки це, на їхню думку, могло завдати шкоди заповідній зоні, до того ж, за твердженням О. Форостюка, суворі аскетичні умови виявилися непосильними для перших послушників і вони залишили скит ${ }^{38}$.

У 2000 р. Луганським єпархіальним управлінням УПЦ Київського Патріархату здійснювались заходи щодо заснування в обласному центрі Хрестоздвиженського монастиря, настоятелем якого був призначений архімандрит Сергій Горобцов ${ }^{39}$ - майбутній архієпископ Донецький і Маріупольський ПЦУ. Утім, досвід заснування монастирів не набув свого широкого втілення серед місцевих єпархії УПЦ Київського Патріархату на Донбасі. Наприкінці 1990-х - початку 2000-х рр. Луганською єпархією УПЦ Московського Патріархату було засновано широку мережу монастирів на території регіону. Зокрема, в 2002 р. монастир був заснований на місці старовинного Свято-Андріївського храму (1893 р.) с. Першозванівка Лутугинського району ${ }^{40}$, в 2003 р. був заснований Свято-Сергіївський монастир у м. Кремінна ${ }^{41}$, в 2005 р. монастир був заснований на місці старовинного СвятоІллінського храму (1861 р.) с. Варварівка Кремінського району ${ }^{42}$, у 2007 р. монастир був заснований на місці старовинного Петро-Павлівського храму (1875 р.) с. Чугинка СтаничноЛуганського району ${ }^{43}$, у 2009 р. монастир був заснований на місці старовинного СвятоРіздвяно-Богородського храму (1881 р.) с. Красний Деркул Станично-Луганського району ${ }^{44}$ а в 2013 р. монастирі були засновані на місці старовинного Вознесенського храму (1910 р.) с. Хороше Слов'яносербського району та Свято-Пантелеймонівського храму м. Луганська ${ }^{45}$. У 1990 рр. істинно-православні християни Луганщини здійснили відчутний вплив на вірних Московського Патріархату, зокрема у ставленні до ідентифікаційних номерів. Однак, варто зауважити, що попри радикальну консервативність парафіяльного життя громад ІПЦ, серед іiї членів цілком можлива місіонерська діяльність, оскільки, для прикладу, згадуваний Г. Цимбал, пройшовши в таборі богословське навчання під керівництвом митрополита Йосифа (Сліпого), став одним з провідних священників УГКЦ на Луганщині ${ }^{46}$.

\footnotetext{
38 Там само. С. 193.

${ }^{39}$ Там само. С. 32.

${ }^{40}$ Сумішин Ю.С., Корнєєв Є.С., Брель Я.М., Кравченко Г.М. Луганська єпархія. Інформаційно-довідкове видання. С. 281.

${ }^{41}$ Северодонецкая епархия 10 лет. Под общ. ред. Высокопреосвященнейего Никодима, архиепископа Северодонецкого и Старобельского. Северодонецк: Информационно-просветительский и издательский отделы Северодонецкой епархии УПЦ. С. 57.

${ }^{42}$ Там само. С. 61-62.

${ }^{43}$ Сумішин Ю.С., Корнєєв Є.С., Брель Я.М., Кравченко Г.М. Луганська єпархія. Інформаційно-довідкове видання. С. 545

${ }^{44}$ Там само. С. 517.

45 Засідання Священного Синоду Української Православної Церкви від 25 квітня 2013 року. URL: https://sinod.church.ua/2014/01/15/zasidanya-25-kvitnya-2013-roku/

${ }^{46}$ Гайворонська Г. Прочанка зі сходу. Донецьк: Каштан, 2012. С. 38-40; Цимбал Г. Третя Московська спокуса (або мої зустрічі з Патріярхом Йосифом). Львів, 1997. 133 с.
} 
Отже, в результаті цілеспрямованих антирелігійних заходів місцевих органів влади на межі 1920-1930-х рр. легальне парафіяльне життя на території Луганської області було майже цілковито припинене. Нищення зазнали не тільки організовані структури усіх реформаційних православних конфесій, але й старовинні громади, серед яких Микільська парафія села Вовкодаєве Новоайдарського району Луганської області. На жаль, внаслідок скрутної економічної ситуації в Україні, пасивної протидії місцевих чиновників розвитку УПЦ Київського Патріархату на Луганщині, українському духовенству не вдалося активізувати парафіяльне життя старовинної Микільської громади. Зважаючи на відсутність умов для відновлення громади із залученням органів державної влади та місцевих політичних еліт, вважаємо за доцільне створення на місці парафії Микільського монастиря, найменування якого мало б символічне значення, перекликаючись з історією першої громади конфесії на території області. 3 огляду на можливість заснування паломницького центру існують перспективи здійснення широкої місіонерської діяльності серед представників опозиційних православних конфесій і подальшого залучення матеріальних ресурсів до відбудови історичної храмової будівлі.

Mykola Ruban

\section{History and Prospects of Restoration of St. Nicholas' Parish of Vovkodaieve Village of Novoaidar District of Luhansk Region}

Abstract: The article attempts to investigate the history of the foundation and prospects of the development of the St. Nicholas' parish of the village of Vovkodaieve, Novoaidar district, Luhansk region. It is given biographical information about the last long-term abbot of the Vovkodaive community - the repressed priest Mitrofan Taranskyi. The circumstances of the institutionalisation of the Orthodox Church in Starobilshchyna, in particular the local eparchy of the renewed Ukrainian Synodal Church, as well as the events surrounding the closure of the church in the village of Vovkodaieve against the general implementation of the antireligious policy of the Soviet party leadership and the liquidation of the structures of isolated Reformation Orthodox denominations in the Luhansk region in the 1930s. Circumstances of returning the expropriated building of St. Nicholas' Church to the restored community as part of the Luhansk-Starobilsk Eparchy of the UOC Kyiv Patriarchate in the early 2000s are clarified. Possible ways to reconstruct the temple building are identified and a strategy for the actual resumption of community activities is proposed. It is proved that with limited resources available, community restoration and revitalization of the church building are possible only if a monastery-pilgrimage center is established on its place, which in turn will allow for effective missionary work among local dissident Orthodox communities. The history of the development of Orthodox monasticism and the experience of forming a network of monasteries on the place of historical churches in the Luhansk region are analyzed.

Keywords: Orthodoxy, Vovkodaievo, St. Nicholas Church, monastery, monasticism, missionary activity 